\title{
Małżeństwo i rozwód w średniowiecznym prawie Hywel Dda (Cyfraith Hywel)
}

Prawem Hywel Dda (Cyfraith Hywel) określa się skodyfikowane około XI w. w Walii prawo, które powstało na bazie zwyczaju sięgającego korzeni celtyckich. Nazwa zbioru wywodzi się od inicjatora kodyfikacji, księcia Hywel Dda, znanego także jako Hywel Dobry ${ }^{1}$. Spisane prawo stało się dla narodu walijskiego symbolem jedności, tożsamości i odrębności, gwarantem pełnej niezależności, a w okresie wojen o suwerenność $\mathrm{z}$ armią angielską pod przywództwem Edwarda I „Długonogiego” - orężem walki z wrogiem. Cyfraith Hywel zebrane zostało w trzech redakcjach: Cyfnerth (Cyfn) obejmującej siedem rękopisów, Blegywryd (Bleg) składającej się z trzynastu rękopisów, w której zebrane zostało prawo południowej Walii, oraz Iorwerth (Ior) obejmującej osiem rękopisów prawa za czasów panowania Llywelyn ap Iorwerth w latach 1194-1240 oraz Llywelyn ap Gruffudd w latach 1246-1282. Oprócz rękopisów sporządzonych w języku walijskim spisane zostały także rękopisy po łacinie (Peniarth MS 28) ${ }^{2}$.

\footnotetext{
${ }^{1}$ Rozwój prawa w średniowiecznej Walii nastąpił w kilku okresach, mianowicie okresie zakończonym kodyfikacją prawa zwyczajowego przez Hywel Dda, zwanego także Hywel Dobry w połowie XI w., okresie uwiecznionym śmiercią Llywelyn ap Gruffudd w 1282 r. oraz okresie po utracie autonomii przez Walię przypieczętowanym Aktem Supremacji z 1536 r., na mocy którego Walia przyjęła angielski system prawny common law. Watkin, który nawiązuje do wpływu prawa rzymskiego na rozwój prawa Walii, ewolucję prawa walijskiego dzieli na trzy główne okresy: okres poprzedzający najazd Rzymian (do około 41-54 r. n.e.), okres rzymski lub okres dominacji rzymskiej (w 48 r. n.e. Rzymianie dotarli do granic Walii i rozpoczęli okupację Wysp Brytyjskich) oraz okres po wycofaniu się legionów rzymskich z terytorium Walii i upadku cesarstwa rzymskiego (od około 411 r. n.e.): T.G. Watkin, The legal history of Wales, Cardiff 2007, s. 8-9; D. Jenkins, Law of Hywel Dda: law texts of medieval Wales, Cardiff 1986, s. 17.

${ }^{2} \mathrm{~W}$ artykule uwzględniono angielskie tłumaczenia Cyfraith Hywel: D. Jenkins, The law of Hywel Dda, Llandysul, Ceredigion 1986; A. Owen, Ancient laws and institutes of Wales, London 1841; A.W. Wade-Evans, Welsh medieval law: being a text of the laws of Howel the Good, Oxford 1909; S.E. Roberts, The legal triads of medieval Wales, Cardiff 2011.
} 
Szeroki zakres regulacji Cyfraith Hywel pozwala na ustawienie tego zbioru obok takich pomników średniowiecznego prawa Wysp Brytyjskich, jak „The Laws and Customs of the Kingdom of England” autorstwa Ranulpha de Glanville ${ }^{3}$ czy szkockich „Regiam Majestatem” i „Quoniam Attachiamenta"4. Cyfraith Hywel regulowało między innymi strukturę dworu królewskiego, kompetencje poszczególnych urzędników dworskich, prawa kobiet, prawo rodzinne, karne, rzeczowe i zobowiązań. Na zbiór składają się następujące księgi: „The Laws of Court” (,The Court Members”, „The Royal Family”, „The King's Officers”), „The Laws of the Country” (,The Laws of Women”, „The Nine Tongued Ones”, „Surety and Contract”, „Land Law”, „Aliens”, „Royal Rights and Administration”, „Family Law”), „The Justices” Test Book” (,The Three Columns of Law”, „The Value of Wild and Tame”, „Trees”, „Houses”, „Equipment”, „The Human Body”, „Corn Damage”)5. Szczególnie interesująca jest część dotycząca praw kobiet „,The Laws of Women", stanowiąca odrębny wycinek prawa osobowego. Mimo wielu ograniczeń w zakresie zdolności procesowej (na przykład kobieta nie mogła sama odpowiadać przed sądem, lecz wyłącznie poprzez swojego męskiego przedstawiciela, który działał w jej imieniu ${ }^{6}$, występować w roli świadka, składać zeznań przeciwko mężczyźnie ${ }^{7}$ czy partycypować w sukcesji ziemi ${ }^{8}$ ) kobieta obdarzona była przywilejami niedostępnymi w innych porządkach prawnych okresu średniowiecza, przede wszystkim w prawie angielskim. W wielu publikacjach pojawia się teza, że Celtowie obdarzali wyjątkowym szacunkiem kobietę, stąd tyle odniesień do jej praw w zbiorze Cyfraith Hywel ${ }^{9}$. Jak podkreślają Dillon i Chadwick:

${ }^{3}$ R. de Glanville, A treatise on the laws and customs of the Kingdom of England, London 1812.

${ }^{4}$ D.M. Walker, A legal history of Scotland. The beginnings to A.D. 1286, Edinburgh 2007.

${ }^{5}$ Podział według D. Jenkins, op. cit., 1986.

${ }^{6} \mathrm{~W}$ tym zakresie kobieta została zrównana do cudzoziemca i osoby cierpiącej na zaburzenia mowy, cytując dokładnie za stosownym fragmentem osoby jąkającej się: „Three persons who are entitled to a representative in court on their behalf: a woman, and a foreign-tongued alien, and a congenital stammerer": S.E. Roberts, op. cit., s. 65. Istniały jednak wyjątki od tej reguły, mianowicie przewidywano syngularną odpowiedzialność kobiety za zabójstwo i kradzież. Kobieta działała także bez przedstawiciela w sprawach spadkowych: „Three cases where a woman is entitled to answer without her husband. One is for the killing of a corpse which she herself kills by an act of hand and foot, the second is for a theft which she commits without her husband, the third is for hereditary owenership of land and earth": ibidem, s. 349.

${ }^{7}$ D. Jenkins, op. cit., s. 57.

${ }^{8} \mathrm{~W}$ niektórych częściach Walii, głównie na południu, można było zauważyć odstępstwa od tej zasady i kobiety w braku następców prawnych płci męskiej dziedziczyły ziemię T.P. Ellis, Welsh tribal law and custom in the Middle Ages, Oxford 1982, s. 387-388.

${ }^{9}$ M. Dillon, N. Chadwick, Ze świata Celtów, Warszawa 1975; P.T. Ellis, Welsh tribal law and custom in the Middle Ages, Milford House 1926; P.B. Ellis, Celtic women. Women in Celtic society and literature, Constable 1996; J. Gąsowski, Mitologia Celtów, Warszawa 1987; E. McCoy, Celtic women's spirituality. accessing the cauldron of life, St. Paul, Minnesota 1998. 
„Nigdy nie zrozumiemy naprawdę ani celtyckiej historii, ani literatury, dopóki nie uświadomimy sobie wysokiej pozycji kobiet celtyckich i nie poznamy miejsca jakie zajmowały w społeczeństwie, zarówno w Galii jak i w Brytanii”10.

Ilustrując to stwierdzenie przykładami, kobiety nie tylko pełniły role matek i strażniczek miru domowego, ale brały także czynny udział w wojnach $^{11}$. Szczególna pozycja kobiety uwydatniona jest w zbiorze Cyfraith Hywel w odniesieniu do żony króla, która otrzymywała jedną trzecią jego dochodów i cieszyła się statusem społecznym większym niż wielu urzędników dworskich $^{12}$. Prawo przyznawało jej odszkodowanie za wyrządzoną szkodę, znane jako sarhaed, w sytuacji zagrożenia jej bezpieczeństwa i naruszenia nietykalności cielesnej, zwłaszcza, jak to pokazuje poniższy wyimek ze zbioru, przez zadanie ciosu, uderzenie czy wytrącenie przedmiotu z ręki:

„In three ways sarhaed is done to the Queen. One is to break her protection. A second is to strike her a blow. A third is to snatch something from her hand"13.

Każda kobieta miała prawo do sarhaed w przypadku zgwałcenia i wymuszenia czynności seksualnej, cytując dokładnie za zbiorem w przypadku obcowania seksualnego z mężczyzną wbrew jej woli, pocałunku bez jej zgody i napastowania. Wysokość sarhaed zależała od stopnia przewinienia:

„These are three sarhaeds of a woman, one which is augmented, one which is decreased, and one which is complete sarhaed: the first is to have intercourse with her against her will, and that is paid to her with one augmentation. The second is to give her a kiss against her will, and that is decreased, a third is lacking from it. The third is to grope her against her will, and that is complete sarhaed to her; and if she is married, it is paid to her according to the status of her husband"14.

Pewne wyjątki od powyższych zasad dotyczyły kobiet uprawiających nierząd, które zostały pozbawione możliwości ubiegania się o odszkodowanie w przypadku gwałtu. Prawo przyznawało jednak takim kobietom odszkodowanie, gdy doszło do innego niż gwałt naruszenia nietykalności cielesnej. Suma odszkodowania, o którym mowa, stanowiła ekwiwalent odszkodowania należnego bratu, kalkulowanego według jego stanu społecznego. W przypadku śmierci kobiety w wyniku przestępstwa, rodzinie była wypłacana od sprawcy i jego krewnych nawiązka w postaci tak zwanego galanas:

\footnotetext{
${ }^{10}$ M. Dillon, N. Chadwick, Ze świata Celtów, Warszawa 1975, s. 35.

${ }^{11}$ Ibidem.

12 T.G. Watkin, op. cit., s. 49.

${ }^{13}$ S.E. Roberts, op. cit., s. 41; D. Jenkins, op. cit., s. 6.

${ }^{14}$ S.E. Roberts, op. cit., s. 105.
} 
„A harlot has no status. Though she be raped, she is not entitled to receive compensation; if she suffers sarhaed, let her sarhaed be paid according to her brother's status, and her galanas if she is killed"15.

Istotne znaczenie dla zrozumienia instytucji małżeństwa w Cyfraith Hywel ma fakt, że było to prawo silnie zakorzenione w zwyczajach Celtów. Podstawową komórką społeczności celtyckiej był ród połączony licznymi więzami podległości i współzależności, a status jednostki wyznaczała pozycja w rodzinie. Status określał zdolność prawną i zdolność do czynności prawnych, zakres odpowiedzialności za przestępstwa ścigane na gruncie prawa prywatnego czy obowiązki fiskalne ${ }^{16}$. Obok statusu kluczowym determinantem społeczności rodowej był honor, którego naruszenie traktowano jako przewinienie szczególnej wagi przeciwko zarówno ofierze jak i jej rodzinie. Powszechnie stosowanym środkiem zapobiegania sporom o naruszenie honoru było wspomniane wyżej odszkodowanie, zwane sarhaed ${ }^{17}$. Inną oznaką zwyczajów rodowo-plemiennych była praktyka kojarzenia związków małżeńskich w obrębie tej samej rodziny czy klanu. Cyfraith Hywel dopuszczało związki małżeńskie pomiędzy najbliższymi krewnymi do trzeciego i czwartego pokolenia, co spotkało się z ostrą krytyką władz kościelnych ${ }^{18}$. Według Ellis ${ }^{19}$, przyzwolenie na zawieranie związków opartych na takim stopniu pokrewieństwa podyktowane było względami ekonomicznymi, mianowicie

${ }^{15}$ D. Jenkins, op. cit., s. 60.

${ }^{16}$ R.R. Davies, Wales: the Age Of Conquest, 1063-1415, Oxford 1987, s. 115-116. Cyfraith Hywel opierało się na złożonym systemie kar pieniężnych za poszczególne czyny przeciwko osobie i mieniu. Kary fizyczne czy kara śmierci nie były powszechnie stosowane, z wyjątkiem niektórych form kradzieży: Szerzej na ten temat między innymi w D. Jenkins, op. cit.; T.G. Watkin, op. cit.

${ }^{17}$ M. Owen, Shame and reparation: women's place in the kin, [w:] The Welsh Law of Women, red. D. Jenkins, M. Owen, Cardiff 1980, s.45. Instytucja odszkodowania obejmowała między innymi galanas oraz sarhaed. Galanas, odszkodowanie należne rodzinie osoby za jej śmierć w wyniku przestępstwa, odpowiadało statusowi społecznemu osoby lub jej opiekuna prawnego; galanas żony było uzależnione od galanas męża, a w przypadku kobiety niezamężnej galanas ojca lub brata. Sarhaed (prawdopodobnie inspirowane rzymskim pojęciem iniuria) z kolei związane było ze stopniem wyrządzonej krzywdy. Specjalną opieką objęte były kobiety brzemienne. W razie uszkodzenia płodu lub poronienia kobieta otrzymywała galanas, wysokość którego wyznaczał stopień zaawansowania ciąży i rozwoju płodu. Więcej na ten temat między innymi w: T.G. Watkin, op. cit., s. 54. Por. Wergili - pojęcie w prawie plemion germańskich odpowiadające odszkodowaniu za zabójstwo lub uszkodzenie ciała i szczególną ochronę kobiety brzemiennej u plemion germańskich, w: S. Bardsley, Women's roles in the Middle Ages, London 2007, s. 130-131.

${ }^{18}$ T.G. Watkin, op. cit., s. 55. Krytyka Cyfraith Hywel przez Kościół, czemu wyraz dała debata zainicjowana przez biskupa Peckhama, prowadziła stopniowo do zaostrzania się sporu pomiędzy Walią a Anglią. Kwestia prawa była zarzewiem długotrwałego konfliktu między prawem kanonicznym, które regulowało relacje rodzinne i małżeńskie w Anglii, a rodzimym i zwyczajowym prawem Walii. Warto w tym miejscu zanotować ostry sprzeciw wysunięty przez Geralda z Walii i arcybiskupa Peckhama w 1292 r. oraz arcybiskupa Theobalda w 1161 r.: R.R. Davies, The age of conquest: Wales 1063-1415, Oxford 1987, s. 127.

${ }^{19}$ Ellis, op. cit., s. 431. 
zapobiegało utracie gwaddol - posagu stanowiącego część posagu ojca, który otrzymywała kobieta, wchodząc w związek małżeński. Ponadto, w obliczu nieustannych konfliktów zbrojnych, konieczne było utrzymanie jak największej liczby urodzeń, co tłumaczy nie tylko występowanie licznych związków opartych na relacji bliskiego pokrewieństwa, ale także społeczną aprobatę separacji i związków pozamałżeńskich, które miały zapobiec wspomnianej zapaści demograficznej. Dopiero wpływ chrześcijaństwa wprowadził istotne zmiany na tym polu ${ }^{20}$. Duchowny i kronikarz Giraldus Cambrensis, znany bardziej jako Gerald z Walii (ok. 1146-1223), w swojej relacji z podróży po Walii w XII w. porusza kwestię kazirodztwa wśród społeczności walijskiej, przytaczając inne powody takiego stylu życia, mianowicie pisze o niezwykłym przywiązaniu do pochodzenia. Gerald wspomina także o przesłankach czysto praktycznych: kojarzeniu związków kazirodczych przyświecała intencja zakończenia sporów w obrębie rodziny czy klanu:

"Incest is extremely common among the Welsh, both in the lower classes and the better educated people. 'There is no fear of God before their eyes', and they have no hesitation or shame in marrying women related to them in the fourth or fifth degree, and sometimes even third cousins. Their usual excuse for abusing the ordinances of the Church in this way is their wish to put an end to some family quarrel or other. [...] Another reason given for their marrying women of their own family is their great respect for noble descent, which means so much to them. They are most unwillingly to marry anyone of another family, who, in their arrogance, they think may be their inferior in descent and blood" 21 .

Analogicznie do większości systemów prawnych epoki wczesnego średniowiecza, Cyfraith Hywel określało gotowość do wstąpienia w związek małżeński na dwanaście lat u kobiet i czternaście lat u mężczyzn. Cykl życia człowieka dzielono na okres siedmiu lat: od urodzenia do siódmego roku życia, od lat siedmiu do lat czternastu i od czternastego do dwudziestego roku życia. Cyfraith Hywel regulowało także okresy, w których kobieta mogła zajść w ciążę. Mimo iż kobieta mogła wstąpić w związek małżeński już w wieku dwunastu lat, prawo zabraniało jej zajścia w ciążę do momentu ukończenia czternastu lat ${ }^{22}$.

${ }^{20}$ S. Heinz, A British Tristan tradition, [w:] Proceedings of the Harvard Celtic Colloquium, red. K. Conley, E. Lehmann-Shriver, S. Zeiser, Cambridge and London 2008, s. 89-128. Dla porównania, w prawie angielskim przestępstwa przeciwko moralności były karane bardzo surowo. Kobieta, która dopuściła się cudzołóstwa była karana obcięciem nosa, uszu czy przepadkiem mienia na rzecz męża. Jeśli została złapana na gorącym uczynku, mąż miał prawo zabić niewierną żonę: K. Koranyi, Powszechna historia państwa i prawa, Warszawa 1963, s. 260.

${ }^{21}$ Gerald of Wales, The journey through Wales and the Description of Wales, translated by Lewis Thorpe, London 2011, s. 263.

${ }^{22}$ T.G. Watkin, op. cit., s. 56-57. 
Małżeństwo w średniowiecznym prawie Walii było zgodnym porozumieniem stron w opozycji do poglądów ukształtowanych przez doktrynę Kościoła katolickiego, dominującą w prawie rodzinnym Anglii, według której związek małżeński utożsamiany był z sakramentem ${ }^{23}$. Według Cyfraith Hywel, małżeństwo było zwykłą umową pomiędzy rodziną kobiety a jej przyszłym mężem. Zawarcie związku małżeńskiego wymagało zgody krewnych (cenedl): ojca, braci lub krewnych płci męskiej do czwartego pokolenia ${ }^{24}$.

Związek małżeński oparty był w pewnym stopniu na relacjach partnerskich, a nie jedynie podległości wobec mężczyzny, jak to miało miejsce na przykład w prawie rzymskim ${ }^{25}$. Kobieta, wchodząc pod opiekę mężczyzny, nie tylko nie traciła swoich praw, ale otrzymywała nowe przywileje ${ }^{26}$, mianowicie gwaddol (posag przekazywany przez rodzinę), agweddi (udział we wspólnym majątku wypłacany kobiecie przez męża, jeśli małżeństwo zostało rozwiązane przed upływem siedmiu lat; był to rodzaj zabezpieczenia na wypadek rozwodu), argyfreu (rzeczy osobiste), cowyll (podarunek od męża przekazywany w noc poślubną, stanowiący zapłatę za utratę dziewictwa), amobr (suma płacona opiekunowi prawnemu kobiety za opiekę) oraz gowyn (odszkodowanie za zdradę męża) ${ }^{27}$.

Dziewictwo było podstawowym warunkiem ważności małżeństwa; pan młody mógł odrzucić kobietę i anulować związek, jeśli w noc poślubną odkrył, że współżyła wcześniej z innym mężczyzną ${ }^{28}$. Stawał wówczas przed gośćmi weselnymi, jak to pokazuje dość dosadnie poniższy fragment, ,z obnażonym męskim przyrodzeniem” i publicznie dawał świadectwo „nieczystości kobiety”:

${ }^{23}$ Ibidem, op. cit., s. 54, R. Davies, op. cit., s. 128. W prawie angielskim małżeństwo tworzyły dwa elementy: affectio maritatlis wyrażone w czasie teraźniejszym w obecności księdza oraz akt fizyczny pomiędzy kobietą a mężczyzną. Konsekwencją takiego podejścia były trudności w rozwiązaniu małżeństwa. Rozwód dopuszczalny był jedynie w kilku sytuacjach: przymus, bigamia, pokrewieństwo, impotencja męża: J. Ward, Women in England in the Middle Ages, New York 2006, s. 43.

${ }^{24}$ T.P. Ellis, op. cit., s. 395.

25 Ibidem, s. 438.

${ }^{26}$ Praktyka składania podarunków z okazji zawarcia małżeństwa była powszechnie znana w średniowieczu. U plemion germańskich istniały dwie inne formy podarunków: wittamon (zapłata składana przez pana młodego rodzinie panny młodej) oraz morgengable (podarunek składany przez męża pannie młodej po nocy poślubnej), S. Bardsley, op. cit., s. 151-152.

${ }^{27}$ T.G. Watkin, op. cit., s. 55; M. Owen, Shame and reparation. Women's place in the kin, [w:] The Welsh Law of Women, red. D. Jenkins, M. Owen 1980, s. 40-69.

${ }^{28}$ Cyfraith Hywel chroniło kobietę przed przemocą seksualną ze strony mężczyzny. Surowo karany był gwałt oraz próby podstępnego zwabienia kobiety w celu odbycia z nią stosunku seksualnego. Kobieta w takiej sytuacji należała do grupy tak zwanych ,the nine-tongued ones” - grupy dziewięciu osób, których zeznania złożone pod przysięgą uznawano za wiarygodne i wiążące. Kobieta mogła wówczas ubiegać się o odszkodowanie. Wysokość odszkodowania należnego kobiecie, która została zmuszona do odbycia stosunku seksualnego przed nocą poślubną, opiewała na odszkodowanie jej świeżo poślubionego męża a nie brata, jak to miało miejsce w odniesieniu do panny: D. Jenkins, op. cit., s. 48, 60, 62. 
„If a maiden is given to a man and is found to be corrupted, but the man suffers her in his bed until the morrow, he cannot on the morrow take away any of her entitlement. If immediately after he finds her to be corrupted he rises to the wedding-guests with his penis erect, and testifies to them that he found her corrupted, and he does not sleep with her until the morrow, she is not entitled on the morrow to anything from him" 29 .

Odtrącona kobieta mogła przeciwstawić stawiane jej zarzuty, opierając się na zeznaniach siedmiu świadków spośród najbliższej rodziny. Innym sposobem potwierdzenia dziewictwa był test przeprowadzany przy pomocy młodego woła; kobieta musiała uchwycić zwierzę za nasmarowany ogon i utrzymać je przez kilka sekund. Jeśli udało się jej to zadanie, otrzymywała agweddi. Jeśli nie zdołała opanować woła, co było znakiem, że świadczyła nieprawdę, została pozbawiana wszelkich przywilejów z okazji zawarcia małżeństwa:

„If she does not want to be vindicated, let her shift be cut off as high as her groin, and let there be put into her hand a yearling steer with its tail greased, and if she can hold it by its tail, let her take it for her share of her agweddi; and if she cannot hold it, let her be without anything" 30 .

Pozyskiwanie dowodów świadczących o odbytym stosunku seksualnym było praktykowane także w dwóch innych sytuacjach, mianowicie w sprawie rozwodowej i sprawie o gwałt. Kobieta, która powoływała się na brak wspólnego pożycia jako powód rozpadu małżeństwa i tym samym bezpośrednią przesłankę jego rozwiązania, musiała odbyć stosunek płciowy z jej partnerem. Ślady męskiej spermy na białym prześcieradle stanowiły niepodważalny dowód istnienia więzi płciowej i tym samym niweczyły jej szanse na rozwód:

„If it happens that a woman says of a man that he cannot have a connexion with her, and because of that seeks to separate from him, law orders her to be tested. This show testing is done: a freshly-laundered white sheet is spread under them, and the man goes to her on it to have her; and when his will comes he ejaculates on the sheet; if it is seen on it, it is a qouta for him, and she cannot separate from him for that cause. Of he cannot do it at all, she can separate from him, and take the whole of what is hers" 31 .

W drugim ze wspomnianych przypadków kobieta występująca z oskarżeniem przeciwko mężczyźnie o gwałt była badana przez oficera na dworze królewskim określanego jako edling:

\footnotetext{
${ }^{29}$ D. Jenkins, op. cit., s. 49.

${ }^{30}$ Ibidem.

${ }^{31}$ Ibidem, s. 59.
} 
„If it happens that a maiden says that a man had raped her and the man denies it, and the maiden says that if he has not raped her she is a maiden: the law says that it is proper to test whether she is a maiden or not a maiden, for the plea is that she is a maiden. It is right that the edling should test her, and if he finds her to be a maiden, the man will be free and she will not lose her status" ${ }^{\prime 32}$.

W Cyfraith Hywel istniały dwa rodzaje związków małżeńskich; pierwszy rodzaj opierał się na tradycyjnym przekazaniu kobiety mężczyźnie przez jej rodzinę lub nabyciu kobiety przez mężczyznę w ramach zawartej umowy, drugi natomiast miał miejsce w przypadku, gdy kobieta współżyła wraz z mężczyzną bez formalnej zgody rodziny ${ }^{33}$. Dwa wspomniane sposoby wstąpienia w związek małżeński obejmowały rod o cenedl oraz lladrut, z czego jak twierdzi Ellis, pierwszy typ miał swój ekwiwalent w rzymskim co-emptio a drugi w rzymskim usus $^{34}$. Podkreślić wypada, że dzieci zrodzone zarówno z rod o cenedl jak i lladrut miały taki sam status prawny. $\mathrm{Na}$ ojcu spoczywał obowiązek uznania wszystkich swoich dzieci, co odbywało się poprzez uroczyste wprowadzenie do rodu - procedura określana jako cynnwys ${ }^{35}$. Przyznanie równego statusu prawnego dzieciom zrodzonym $\mathrm{w}$ małżeństwie i w związku nieformalnym nie wynikało, jak można sądzić, z aprobaty rozwiązłego trybu życia ${ }^{36}$, lecz jak twierdzi Walters ${ }^{37}-\mathrm{z}$ braku sformalizowanej procedury zawarcia związku małżeńskiego i stosunkowo łatwego jego rozwiązania. Prawo dopuszczało życie w konkubinacie i po upływie siedmiu lat taki związek wywoływał takie same skutki prawne jak małżeństwo ${ }^{38}$. Cyfraith Hywel zakazywało jednak bigamii ${ }^{39}$.

Status społeczny męża określał status społeczny żony. Sarhaed kobiety zamężnej stanowiło trzecią część odszkodowania należnego jej mężowi,

\footnotetext{
${ }^{32}$ Ibidem.
}

${ }^{33}$ Nieformalny związek kobiety i mężczyzny miał na przykład miejsce, gdy kobieta uciekła z kochankiem z domu rodzinnego. Prawo przewidywało możliwość zmuszenia jej do powrotu do rodziny, ale tylko pod warunkiem, że pozostawała dziewicą. Jeśli doszło do kontaktu intymnego pomiędzy nią a mężczyzną, ingerencja krewnych nie rodziła skutków prawnych. D. Jenkins, op. cit., s. 52.

${ }^{34}$ T.P. Ellis, op. cit., s. 393.

${ }^{35}$ R. Davies, op. cit., s. 128.

${ }^{36}$ Istnieje zapis, który wyraźnie potępia rozwiązłość i cudzołóstwo. Zachowania uwłaczające kobiecie są wymienione wprost. Kobieta mogła być posądzona o cudzołóstwo lub rozwiązły tryb życia, gdy została dosłownie ,przyłapana” „wraz z mężczyzną pod jednym kocem”, „z mężczyzną między udami” albo „,z mężczyzną w krzakach bądź w niezamieszkanym budynku”: „If it happens that a woman is seen coming from one side of a grove and a man on the other, or coming from an empty house, or under one mantle, if they deny it, the oath of fifty women for the woman, and as many men for the man": D. Jenkins, op. cit., s. 57.

${ }^{37}$ D.B. Walters, The European legal context of the Welsh law of matrimonial property, [w:] The Welsh law of women, red. D. Jenkins, M. Owen 1980, s. 106.

${ }^{38}$ D. Jenkins, op. cit., s. 50.

${ }^{39}$ Ibidem, s. 52. 
a w przypadku kobiety niezamężnej połowę odszkodowania należnego bratu. Galanas wynosiło zawsze połowę galanas brata:

"The sarhaed of a married woman, a third of her husband's sarhaed' if she is not married, half the sarhaed of her brother. Her galanas, whether single or married, half her brother's galanas" 40 .

Prawo określało podstawowe obowiązki kobiety względem męża, takie jak obowiązek obcowania płciowego, zakaz używania wulgarnych słów pod jego adresem ${ }^{41}$ oraz zakaz sprzedaży lub darowizny ruchomości należących do wspólnego majątku, co było karane karą pieniężną lub cielesną. Kara pieniężna stanowiła określoną sumę uiszczaną przez kobietę mężowi za każde słowo uwłaczające jego godności. Mąż mógł karać żonę fizycznie ${ }^{42}$; kara polegała na „trzech uderzeniach za pomocą kija o długości męskiego przedramienia i grubości serdecznego palca u ręki, w każdym miejscu na ciele z wyjątkiem głowy":

„If it happens that a woman says shameful words to her husband, such as wishing a blemish on his beard or dirt in his teeth, or calling him a cur, law judges the payment of a camlwrw to her husband for every one of them, for every woman's husband is her lord, or if he prefers it, let him strike her three blows with a rod as long as a man's forearm and as thick as a long finger, in any place except her head"43.

Co więcej, żona płaciła mężowi sarhaed, gdy dopuściła się cudzołóstwa. Powołując się dosłownie na zapis w zbiorze, wystarczającą przesłanką do odszkodowania był jakikolwiek kontakt fizyczny z obcym mężczyzną począwszy od zwykłego pocałunku na stosunku seksualnym skończywszy. W tym ostatnim przypadku suma sarhaed była zwiększana o połowę:

„If it happens that a woman commits a gross offence, whether giving a kiss or allowing fondling or copulation with her, that is sarhaed to her husband. If intercourse with her happens, that sarhaed is augmented by one half, for it derives from kin-feud"44.

40 Ibidem, s. 47.

41 Odczytując ten zapis dosłownie, żonie przypisywano winę za obrazę męża, gdy ,życzyła mu skazy na brodzie”. Słowo „,broda” nie jest tu użyte przypadkowo, lecz odnosi się do symbolu mądrości, wiedzy, siły itp., które były typowymi atrybutami kojarzonymi z autorytetem i wyższym statusem społecznym męża. S.E. Roberts, op. cit., s. 181, 313.

42 Dla porównania, prawo angielskie jedynie zakazywało „nadmiernej” przemocy względem żony. Mąż miał zatem niczym nieograniczone prawo karania cielesnego swojej żony: S. Bardsley, op. cit., London 2007, s. 106.

${ }^{43}$ D. Jenkins, op. cit., s. 53.

${ }^{44}$ Ibidem, s. 48. 
Od tej zasady przewidywano pewne wyjątki, mianowicie jeśli do kontaktu cielesnego doszło podczas zabawy lub gdy kobieta padła ofiarą napastowania ze strony cudzoziemca nieobeznanego z prawem i lokalnymi zwyczajami:

„Here are the three cases in which a man is not entitled to compensation from his wife though they be admitted: for fondling her when playing rhaffan, or in a carouse, or if a man from afar from a strange country should fondle her before knowing the law of the country"45.

Żona zatem nie miała prawa naruszać w żaden sposób autorytetu swojego męża, który był jej prawnym opiekunem. Wszelkie oskarżenia, jeśli takowe chciała skierować przeciwko własnemu mężowi, podnosząc zarzut bezprawnego uszkodzenia ciała musiała poprzeć grupą świadków. Cyfraith Hywel zabraniało karać żonę podwójną sankcją, czyli zarówno karą finansową jak i cielesną. Ponadto, zdrada ze strony męża była podstawą do wypłaty żonie odszkodowania zwanego gowyn, którego suma wzrastała wraz z liczbą przygodnych kontaktów seksualnych. W przypadku trzeciej zdrady męża, żona mogła wnosić o rozwiązanie małżeństwa ${ }^{46}$.

Małżeństwo rozwiązywało się poprzez rozwód zarówno z inicjatywy męża, jak i żony. Do głównych przesłanek rozwodu po stronie męża należały utrata dziewictwa przed zawarciem związku małżeńskiego oraz cudzołóstwo. Prawo do rozwodu miała także żona w trzech przypadkach. Po pierwsze, kiedy mąż cierpiał na trąd. Po drugie, kiedy miał nieświeży oddech. I wreszcie, gdy nie był w stanie $\mathrm{z}$ nią współżyć ze względu na swą impotencję ${ }^{47}$. W każdej z tych trzech sytuacji kobieta zatrzymywała agweddi:

„For three reasons a woman does not lose her agweddi although she leaves her husband: namely for leprosy, and bad breath, and the want of intercourse" 48 .

Analizując powyższy fragment, trudno nie zauważyć, że powody, dla których kobieta mogła opuścić męża są ściśle związane z prokreacją, postrzeganą jako najważniejszy element związku kobiety i mężczyzny w społeczności celtyckiej. Roberts sugeruje, że powyższy opis można potraktować również jako przykład średniowiecznego humoru ${ }^{49}$. Związek małżeński rozwiązywał się z mocy prawa, gdy mąż zdradził żonę, dokładnie rzecz biorąc, popełnił trzecią z kolei zdradę. W takiej sytuacji kobieta mogła liczyć na cowyll, go-

\footnotetext{
${ }^{45}$ Ibidem.

46 Ibidem, s. 53.

${ }^{47}$ D. Jenkins, op. cit., s. 46; S.E. Roberts, op. cit., s. 43.

${ }^{48}$ S.E. Roberts, op. cit., s. 43.

${ }^{49}$ Idem, Emerging from the bushes: the Welsh law of women in the legal triads, Csana Yearbook, Dublin 2008, s. 63.
} 
wyn oraz sarhaed ${ }^{50}$. Kobieta zachowywała zawsze trzy przywileje, cowyll, argyfreu i wynebwerth, nawet jeśli do rozpadu małżeństwa dochodziło z jej winy:

„Three things are not taken from a woman although she is left for her offence: her cowyll, and her argyfreu, and her wynebwerth" ${ }^{15}$.

Prawo wprowadzało okres dziewięciu dni na uprawomocnienie się rozwodu; kobieta musiała wówczas pozostać w domu męża do dziewiątego dnia. Po upływie tego okresu miała prawo opuścić wspólne gospodarstwo. Cyfraith Hywel przewidywało także możliwość powrotu żony do domu męża, jeśli ten żałował rozpadu małżeństwa. Musiało to nastąpić jednak w krótkim czasie po „wyjściu żony ze wspólnego domu” albo „opuszczeniu wspólnego łoża”, cytując dokładnie fragment ze zbioru: gdy ,jedna stopa jest jeszcze we wspólnym łożu, a druga już poza nim":

„If a man takes another wife after separating from the first, the first will be free. If it happens that a man separates from a woman, and the latter takes another man, and the first man regrets separating from his wife, and that he overtakes her with one foot in the bed and the other outside the bed, the first man is entitled to have the woman" 52 .

Prawo zapewniało kobiecie brzemiennej opiekę finansową ze strony byłego męża - ojca dziecka. Kobieta otrzymywała zabezpieczenie finansowe od mężczyzny w zamian za sprawowanie opieki nad dzieckiem aż do momentu ukończenia przez nie lat czternastu. Wówczas ojciec przekazywał syna pod opiekę króla, co wiązało się z obowiązkiem służby wojskowej w drużynie królewskiej ${ }^{53}$.

Podział majątku uzależniony był od wielu czynników: stażu małżeńskiego, winy, śmierci współmałżonka lub umowy. Istotne znaczenie miał fakt, czy istniała przyczyna rozpadu małżeństwa, a zatem jeśli małżeństwo rozpadało się z winy żony, ta traciła wszelkie przynależne jej prawa i korzyści (z wyjątkiem cowyll, argyfreu i wynebwerth), natomiast jeśli to żona opuszczała męża bez podania przyczyny, traciła agweddi, gwaddol, zachowując jedynie cowyll lub gowyn ${ }^{54}$. W przypadku rozwodu znaczenie odgrywał staż małżeński, mianowicie fakt, czy rozwód miał nastąpić przed, czy po upływie siedmiu lat. Jeśli do rozpadu małżeństwa dochodziło przed upływem siedmiu lat, ko-

\footnotetext{
${ }^{50}$ S.E. Roberts, Legal..., s. 46.

${ }^{51}$ Ibidem, s. 45.

${ }_{52}^{52}$ D. Jenkins, op. cit., s. 47.

${ }^{53}$ Ibidem, s. 51.

${ }^{54}$ D.G. Watkin, op. cit., s. 56; D. Jenkins, op. cit., s. 46.
} 
bieta zachowywała agweddi, gwaddol, cowyll i argyfreu. Po upływie siedmiu lat majątek był dzielony. Wobec zgonu jednej ze stron, druga wchodziła we władanie całym majątkiem, z tym jednak zastrzeżeniem, że kobieta nie mogła dziedziczyć po swoim mężu zboża ${ }^{55}$.

Podział majątku nie opierał się na jasno określonych zasadach. O podziale majątku nie decydował status społeczny małżonków ani to, co każda ze stron do tego małżeństwa wniosła. W pierwszej kolejności podziałowi podlegały zwierzęta. Jeśli do podziału przypadały świnie i owce, mężczyzna zatrzymywał świnie, a kobieta owce. Jeśli natomiast dzielono owce i kozy, mężczyzna zatrzymywał owce, a kobieta kozy. W przypadku gdy para miała zwierzęta jednego gatunku, czyli tylko świnie, owce lub kozy, zwierzęta dzielono po połowie, w równych częściach. Mężczyzna miał do swojej dyspozycji także wszystkie kury i jednego kota. Prawo ściśle określało podział wszelkich ruchomości składających się na wspólny majątek; były to głównie urządzenia codziennego użytku służące do prowadzenia gospodarstwa i utrzymania rodziny. Zgodnie z prawem mężczyzna nabywał w wyłączne posiadanie następujące rzeczy: naczynia służące do picia, sito lub przetak, kocioł, poduszki, radlicę, siekierę, świder, żuraw i kosy z wyjątkiem jednej kosy dla żony. Kobiecie przypadały naczynia do picia i przechowywania mleka (z wyjątkiem jednego naczynia, które mógł zatrzymać mąż), sitko, patelnia, trójnóg, topór, lemiesze, pług oraz kosztowności oprócz srebra i złota. Ze względu na to, że to kobieta miała obowiązek opuścić wspólny dom, mogła wykorzystać w tym celu powóz do transportu swoich pakunków. Co do młynka, mężczyźnie przypadała wierzchnia, a kobiecie spodnia jego część. Nie sposób pominąć kwestii pościeli. Mężczyzna zatrzymywał pościel, na której para spała podczas trwania pożycia małżeńskiego aż do momentu, kiedy wziął sobie za żonę inną kobietę. Wówczas pościel ze wspólnego łoża mogła być przekazana byłej żonie. Jeśli inna kobieta legła wraz z mężczyzną na takiej pościeli przed formalnym rozwiązaniem małżeństwa, płaciła byłej żonie partnera odszkodowanie pod postacią tak zwanego wynebwerth. Co się tyczy jedzenia, mężczyzna otrzymywał żywność już gotową do spożycia, cytując dosłownie: ,jedzenie wiszące na hakach", kobieta jedzenie w solance czy marynacie, masło i ser pozostałe do konsumpcji oraz mąkę w takiej ilości, ile zdołała unieść ze spiżarni. Każda ze stron zatrzymywała własne ubrania. Opieka rodzicielska nad dziećmi pochodzącymi ze związku przypadała w ten sposób, że mężczyzna sprawował opiekę nad najstarszym i najmłodszym synem. Długi, jeśli takowe istniały, były dzielone po połowie ${ }^{56}$.

Warto zastanowić się przez chwilę nad samą dystrybucją dóbr majątkowych, która na pierwszy rzut oka wydaje się pozbawiona jakiegokolwiek sen-

\footnotetext{
55 T.D. Watkin, op. cit., s. 56.

${ }^{56}$ D. Jenkins, op. cit., s. 45-46.
} 
su. Możemy zadać pytanie: dlaczego mężczyzna otrzymywał wszystkie kury, skoro miał tylko jednego kota? Jaki użytek mogła uczynić kobieta z pługa, lemiesza czy topora, które kojarzą się z typowo męskimi zajęciami? Wnikliwa analiza powyższego fragmentu pozwala na wnioski, które wykraczają poza sztywne granice prawa i skłaniają czytelnika do przeświadczenia, że mamy tu do czynienia nie z regułami postępowania, ale z pewną metaforą rozpadu związku mężczyzny i kobiety. Ku takiej interpretacji przychyla się także Stacey $^{57}$, która obstaje przy opinii, że „The Laws of Women” należy badać pod kątem literackim. Twierdzi ona, że autor tej części zbioru praw stworzył swoistego rodzaju rozprawę o konsekwencjach rozpadu małżeństwa. Najdobitniej ilustrują to dwa elementy młynka, które po połowie przypadają kobiecie i mężczyźnie. Kres ciągłości więzi, jaka łączyła mężczyznę i kobietę, prowadzi nieuchronnie do upadku kobiety i mężczyzny, zarówno w aspekcie ekonomicznym jak i osobistym. Pozbawieni niezbędnych do uprawy narzędzi: mężczyzna pługa, topora czy lemiesza, a kobieta siekiery, świdra czy kosy, nie są w stanie samodzielnie egzystować. Mężczyzna, co prawda, otrzymywał kury, ale z jednym kotem nie był w stanie odpędzić drapieżników. Nie miał także topora, a więc pozbawiony był możliwości obrony przed nieprzyjacielem. Z drugiej strony można przyjąć, że ów fragment nie ma podtekstów literackich, a sam podział jest umowny. W rzeczywistości podział majątku dokonywany był zapewne po uprzednich ustaleniach w obrębie rodu.

W konfrontacji prawa Cyfraith Hywel z innymi kulturami prawnymi okresu średniowiecza, przede wszystkim prawem angielskim, zarysowuje się odmienne rozumienie roli kobiety i jej statusu prawnego. Cyfraith Hywel dopuszczało między innymi możliwość rozwodu, konkubinatu, przyznawało status prawny dzieciom z nieprawego łoża. Można także zaryzykować hipotezę, że prawo to było niezwykle liberalne jak na czasy, w którym powstało. $\mathrm{Na}$ mocy The Statute of Wales z $1284 \mathrm{r}^{58}$ i po licznych atakach ze strony Kościoła Edward I dokonał licznych zmian w prawie Walii, zastępując rodzime zwyczaje tradycjami angielskimi, co spotkało się z ostrym sprzeciwem ze strony Walijczyków. Mimo iż Cyfraith Hywel przestało formalnie obowiązywać, pozostało ono w świadomości Walijczyków symbolem tożsamości narodowej, czemu dano najpełniej wyraz w poezji epoki późnego średniowiecza.

\footnotetext{
${ }^{57}$ R.C. Stacey, Divorce. Medieval Welsh Style, „Speculum” 77.4. 2002, s. 1107-1127.

${ }^{58}$ I. Bowen, The statutes of Wales, London 1905.
} 
